\title{
Effect of pressure after casting on high strength fibre reinforced mortar
}

\author{
Silvio Delvasto*, Antoine E. Naamant and James L. Thronef
}

\begin{abstract}
Synopsis This study investigates the effects of applying pressure after casting on the flexural response of high strength fibre reinforced mortar in which up to $5 \%$ fibres by volume were premixed. High mortar strength was achieved by reducing mix porosity (low water-cement ratio), adding fly ash and using superplasticisers. Variables included eight different types of fibre, their volume fraction in the mix, two mortar matrices, two values of pressure after casting, and the casting orientation. It is found that pressure improves the proportional limit and the flexural strength of the composite but may lead to a deterioration in its postcracking response and toughness. Composite moduli of rupture of more than 5000 psi (37 MPa) are observed with steel fibres while highest toughness indices of up to 90 are reported with polypropylene fibres. It is concluded that the application of pressure after casting to improve composite properties is not economically justifiable.
\end{abstract}

Keywords Fibre cement composites, pressure compaction, steel fibres, polypropylene fibres, glass fibres, carbon fibres, modulus of rupture, toughness, ductility, elastic modulus, mortars (material), strength of materials, failure.

\section{INTRODUCTION}

It is generally agreed that the main shortcomings of hydraulic cement matrices (paste, mortar, concrete) are their low tensile strength and brittleness at failure. These shortcomings can be improved by addition of short strong discontinuous fibres leading to what is called a fibre reinforced cementitious composite or fibre reinforced concrete (FRC). Among the most desirable properties of fibre reinforced concrete is its tensileflexural strength and its toughness or energy absorbing capability to failure. Continuous research is being currently undertaken to improve these properties.

The mechanics of tension strengthening is either due to the elastic extension of the fibres after matrix cracking, such as in the case of polypropylene fibres, or to the fibre pullout resistance such as in the case of steel fibres. Although an increase in tensile strength may lead to a more than proportional increase in toughness should multiple cracking occur, the increase in toughness is attributed primarily to the pullout mechanism of the fibres.

Little work has been published on the use of fibres in

\footnotetext{
* Professor, Materials Engineering, Universidad del Valle, Cali, Colombia

† Professor, Department of Civil Engineering. University of Michigan. Ann Arbor, Michigan. U.S.A.

$\ddagger$ Research Associate, Amoco Chemical Corporation. Naperville Illinois
}

(C) Longman Group UK Ltd 1986 high strength concrete $[1,2]$. Here high strength indicates strengths in compression of the order of 10 to 15 ksi (69 to $104 \mathrm{MPa}$ ). Because the brittleness of concrete (characterised by its post-peak softening response) increases with its strength, it seems desirable to improve its toughness by addition of fibres. High strength is achieved by a reduction in porosity, hence in water-cement ratio. However, the addition of fibres generally requires higher water content to maintain workability of the mix. Thus a trade-off must be made when using a high volume content of fibres in a high strength cement matrix

The main objective of this research was to study the effect of pressure after casting on the flexural response of high strength fibre reinforced mortar containing a relatively high volume fraction of fibres. High strength was achieved by the use of low water-cement ratios and a superplasticiser. Variables included eight different types of fibres, their volume fraction in the mix, two mortar matrices, and the casting orientation.

This research is significant for the production of high strength cementitious composites such as in the cement sheet industry (asbestos cement, tiles, etc.,). It is also important if the brittleness of high strength concrete is to be overcome in some structural applications, since the addition of fibres improves significantly the toughness of the material

\section{EXPERIMENTAL PROGRAMME}

The experimental programme explored the influence of various parameters on the static flexural strength of fibre reinforced mortar. These included primarily the pressure- 
compaction after casting, the water-cement ratio, the casting orientation, and the fibre volume and fibre type. The objective was to decrease as much as possible the water-cement ratio (hence increase matrix strength) and increase as much as possible the volume content of fibres while keeping the mix workable. In most of the mixes described the workability (or plasticity) could be characterised by a consistency less than normal. A large number (14) of exploratory mixes were tried [3]. Two are described here (Table 1) and are numbered 4 and 5 as identified in [3]. Thirty-eight series of fibre reinforced mortar flexural beams were made with these two mixes and tested. They are described in Table 2. The first two letters of the code designation of each series represent the fibre type (i.e. $P$ for polypropylene) and the mix number (i.e. 4 or 5). The following letters represent when applicable the variety of fibre (i.e. Polypropylene A, B, or C), whether the specimens were pressed after casting or not (i.e. $P$ for pressed), and a number representing identical series prepared at different times.

\section{Mortar matrix}

The two matrices selected have similar dry composition and workability but different water-cement ratios, hence different flexural strengths. The dry mortar consisted of ASTM Type I portland cement, a fine silica sand (Ottawa passing ASTM sieve No. 40), and fly ash. The mix proportions by weight and corresponding flexural and compressive strengths are summarised in Table 1. Note that a type A superplasticiser (trade name Melment) was also used to maintain the desired workability

\section{Fibres}

Several types of fibres were used in the form of randomly distributed discontinuous reinforcement. They are described in Table 3 and include three varieties of polypropylene fibres, carbon fibres in two lengths, steel fibres, glass fibres, and asbestos fibres. Some relevant properties of these fibres as provided by their manufacturer (or as obtained from previous studies) are shown in Table 4.

\section{Specimen preparation}

The component materials were mixed using a Hobart type food mixer. Cement and half of the water were first mixed. Then, the sand, fly ash, and the remaining water were added followed by the superplasticiser. The fibres were then slowly dispensed. The fresh mix was cast and compacted in flexural moulds according to three different methods. In the first two methods the specimens were cast either vertically or horizontally (Figure 1a and $1 \mathrm{~b})$ in plexiglass moulds and externally vibrated on a vibrating table. This was done to compare differences due to filling direction and compaction. In the third method the specimens were cast horizontally in steel moulds, vibrated, finished, then immediately put under pressure (Figure 1c) using a universal testing machine. A pressure of either $4.5 \mathrm{~N} / \mathrm{mm}^{2}$ (650 psi) or $9 \mathrm{~N} / \mathrm{mm}^{2}(1300$ psi) was applied for about 15 minutes to expel surplus water. The pressed beams were 12 in $(300 \mathrm{~mm})$ long, $2 \mathrm{in}$ $(50 \mathrm{~mm})$ wide and of thickness as measured, ranging from 0.25 to 0.75 in $(6$ to $19 \mathrm{~mm})$. The nonpressed specimens were 12 in $(300 \mathrm{~mm})$ long, 3 in $(75 \mathrm{~mm})$ wide and $0.5 \mathrm{in}(12.5 \mathrm{~mm})$ thick

\section{Curing and testing}

Following casting the moulds were placed in a humid enclosure $\left(100 \% \mathrm{RH}\right.$ and $\left.72^{\circ} \mathrm{F}\right)$ for 24 hours. The specimens were then removed and stored in a fog room $\left(100 \% \mathrm{RH}\right.$ and $\left.75^{\circ} \mathrm{F}\right)$ for about 60 days. Then they were stored in a laboratory environment for 1 day prior to testing. Testing was undertaken using an Instron Uni. versal Testing machine. Two point loading was applied on a 10 in $(250 \mathrm{Mm})$ span with a 4 in $(100 \mathrm{~mm})$ constant bending moment zone (Figure 2). The load-deflection curves were automatically plotted on an $X-Y$ recorder The beams were generally loaded to failure or up to 0.5 in $(12.5 \mathrm{~mm})$ deflection. whichever occurred first. Each series of tests comprises three to six specimens Observed results are described next

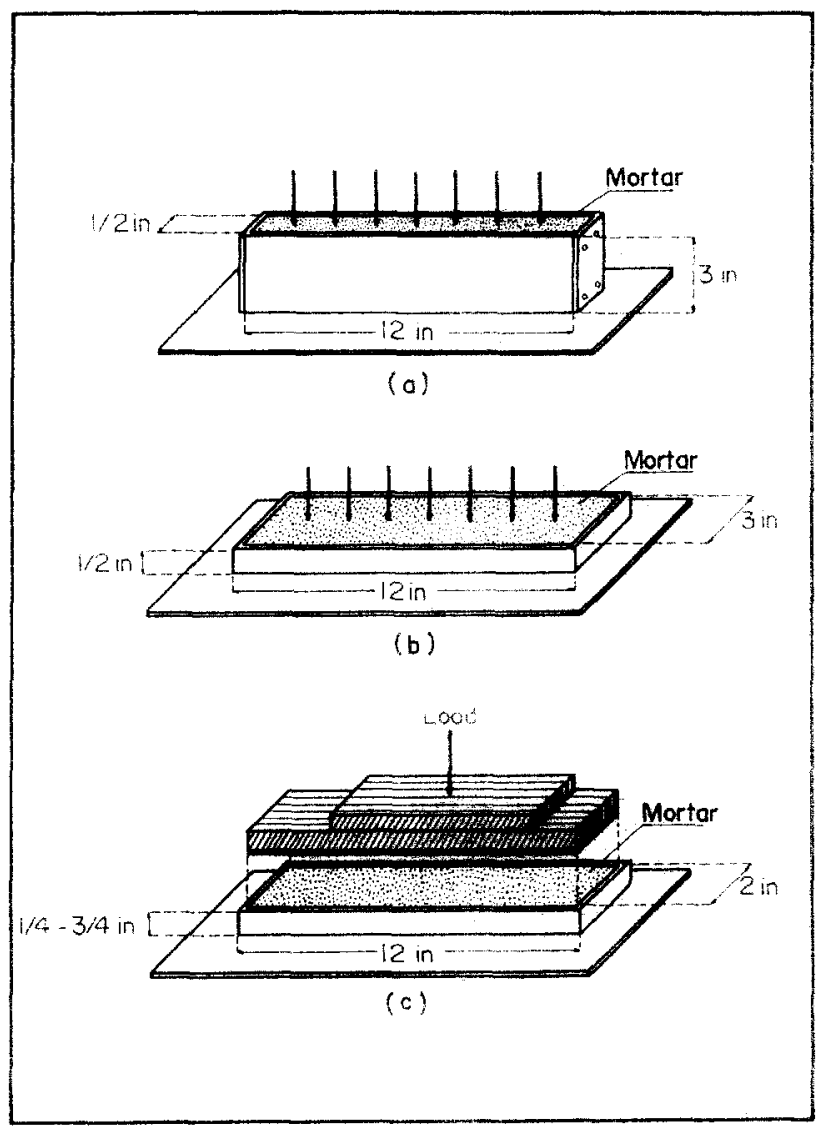

Figure 1 Methods of specimen casting. (a) Vertical, (b) Horizontal, (c) Pressed 
Table 1 Properties of mortar mixes used

\begin{tabular}{lcrr}
\hline Components & Ratio by weight & Mix 4 & \multicolumn{1}{c}{ Mix 5 } \\
\hline Type I portland cement, C & $\mathrm{C}=1$ & 1.00 & 1.00 \\
Fine silicious (Ottawa) sand, S & $\mathrm{S} / \mathrm{C}$ & 0.20 & 0.20 \\
Fly ash, FA & $\mathrm{FA} / \mathrm{C}$ & 0.20 & 0.20 \\
Water, W & W/(C+FA) & 0.30 & 0.24 \\
Superplasticiser, Melment & $\mathrm{SP} / \mathrm{C}$ & 0.023 & 0.05 \\
Compressive strength, 90 days, psi (MPa) & & $11278(77.8)$ & $14609(100.8)$ \\
Flexural strength, 60 days, psi (MPa) & & $732(5.0)$ & 978 (6.7) \\
Tensile strength, 28 days, psi (MPa) & & $549(3.8)$ & 584 \\
Specific gravity & & 2.21 & $(4.0)$ \\
& & & 2.24 \\
\hline
\end{tabular}

Table 2 Test series code designation and characteristics

\begin{tabular}{|c|c|c|c|c|}
\hline $\begin{array}{l}\text { Series code } \\
\text { designation }\end{array}$ & Fibre & Mix & Process & $\begin{array}{c}\text { Volume fraction } \\
\text { of fibres, } V_{f} \%\end{array}$ \\
\hline P4AP1 & Polyprop.A & 4 & Pressed & 5.0 \\
\hline P4AP2 & Polyprop.A & 4 & Pressed $\left({ }^{*}\right)$ & 5.0 \\
\hline$P 4 A$ & Polyprop.A & 4 & Hand Laid & 5.0 \\
\hline P5A5P & Polyprop.A & 5 & Pressed & 5.0 \\
\hline P5A5 & Polyprop.A & 5 & Hand Laid & 5.0 \\
\hline P5A3P & Polyprop.A & 5 & Pressed & 3.0 \\
\hline P5A3 & Polyprop.A & 5 & Hand Laid & 3.0 \\
\hline $\mathrm{P} 4 \mathrm{BP}$ & Polyprop. B & 4 & Pressed & 2.5 \\
\hline P4B & Polyprop.B & 4 & Hand Laid & 2.5 \\
\hline P5BP & Polyprop. B & 5 & Pressed & 3.7 \\
\hline P5B & Polyprop.8 & 5 & Hand Laid & 3.7 \\
\hline$P 4 C P$ & Polyprop.C & 4 & Pressed & 4.0 \\
\hline P4C & Polyprop.C & 4 & Hand Laid & 4.0 \\
\hline P5CP & Polyprop.C & 5 & Pressed & 3.1 \\
\hline P5C & Polyprop.C & 5 & Hand Laid & 3.1 \\
\hline S4P & Steel & 4 & Pressed & 5.0 \\
\hline S4 & Steel & 4 & Hand Laid & 5.0 \\
\hline S5A1 & Steel & 5 & $\begin{array}{l}\text { Hand Laid in } \\
\text { Horizont. mould }\end{array}$ & 5.0 \\
\hline S5A5 & Steel & 5 & $\begin{array}{l}\text { Hand Laid in } \\
\text { Vertical mould }\end{array}$ & 5.0 \\
\hline S5BP & Steel & 5 & Pressed & 2.1 \\
\hline S58 & Steel & 5 & Hand Laid & 2.1 \\
\hline C4AP & Carbon A & 4 & Pressed & 1.5 \\
\hline C4A & Carbon A & 4 & Hand Laid & 1.5 \\
\hline $\mathrm{C} 4 \mathrm{BP}$ & Carbon $B$ & 4 & Pressed & 1.7 \\
\hline $\mathrm{C} 4 \mathrm{~B}$ & Carbon B & 4 & Hand Laid & 1.7 \\
\hline C5AP & Carbon A & 5 & Pressed & 1.9 \\
\hline C5A & Carbon A & 5 & Hand Laid & 1.9 \\
\hline C5BP & Carbon B & 5 & Pressed & 1.9 \\
\hline $\mathrm{C} 58$ & Carbon B & 5 & Hand Laid & 1.9 \\
\hline G4P & Glass & 4 & Pressed & 5.0 \\
\hline G4 & Glass & 5 & Hand Laid & 5.0 \\
\hline G5P & Glass & 5 & Pressed & 2.5 \\
\hline G5 & Glass & 5 & Hand Laid & 2.5 \\
\hline$A 5 P$ & Asbestos & 5 & Pressed & 1.9 \\
\hline $\mathrm{A} 5$ & Asbestos & 5 & Hand Laid & 1.9 \\
\hline MAP & Plain Mortar & 4 & Pressed & 0.0 \\
\hline M4 & Plain Mortar & 4 & Hand Laid & 0.0 \\
\hline M5P & Plain Mortar & 5 & Pressed & 0.0 \\
\hline M5 & Plain Mortar & 5 & Hand Laid & 0.0 \\
\hline
\end{tabular}

The Pressure in the Pressed Series was $50 \mathrm{~kg} / \mathrm{cm}^{2}$ except (*) pressed at $100 \mathrm{~kg} / \mathrm{cm}^{2}$. 


\section{TEST RESULTS AND DISCUSSION}

To eliminate the effect of specimen geometry on the load deflection response of the beams tested, all results are reported in terms of the equivalent elastic flexural stress as obtained from the following equation:

$$
\sigma=\frac{M}{Z}=\frac{9 P}{b d^{2}}
$$

$$
\begin{aligned}
& \text { where } \sigma \quad=\text { equivalent elastic flexural stress } \\
& \mathrm{M}=\text { magnitude of moment in constant } \\
& \text { moment zone } \\
& Z \text { = section modulus } \\
& \text { b }=\text { beam width } \\
& \mathrm{d}=\text { beam depth } \\
& \mathrm{P} \quad=\text { applied load }
\end{aligned}
$$

Table 5 summarises the average results obtained. The stress at the limit of proportionality (LOP) corresponds to first cracking and was obtained at the point of deviation from the initial linear portion of the load deflection curve. The modulus of rupture was obtained from the maximum load after cracking. Corresponding deflections are also reported in Table 5 . The influence of

\begin{tabular}{|c|c|c|c|c|}
\hline Fibre & Type & $\begin{array}{c}\text { Fibre diameter } \\
\text { (or equivalent) } \\
\text { inch (mm) }\end{array}$ & $\begin{array}{l}\text { Fibre } \\
\text { length } \\
\text { in (mm) }\end{array}$ & Supplier \\
\hline $\begin{array}{l}\text { Polypropylene } \\
\text { A }\end{array}$ & $\begin{array}{l}\text { Chopped fibres two-ply } \\
\text { twisted ribbon yarn }\end{array}$ & $2 \times 5000^{*}$ & $\stackrel{1}{(25)}$ & AMOCO \\
\hline $\begin{array}{l}\text { Polypropylene } \\
\text { B }\end{array}$ & Mesh Type A-5 & 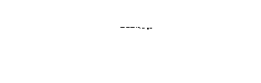 & $\begin{array}{l}0.75 \\
(19)\end{array}$ & Forta Fibre, Inc. \\
\hline $\begin{array}{l}\text { Polypropylene } \\
\text { C }\end{array}$ & $\begin{array}{l}\text { Resin European Fibres, } \\
\text { Chopped Staple }\end{array}$ & $2.8 \mathrm{D}$ & $\begin{array}{l}0.8 \\
(20)\end{array}$ & AMOCO \\
\hline $\begin{array}{l}\text { Carbon } \\
\text { A }\end{array}$ & $\begin{array}{l}\text { Type C-20-PVP } \\
\text { Celion } 12000 \\
\text { (12000 Filaments) }\end{array}$ & $\begin{array}{l}0.28 \times 10^{3} \\
\left(7 \times 10^{3}\right)\end{array}$ & $\begin{array}{l}0.75 \\
119)\end{array}$ & Celanese \\
\hline $\begin{array}{l}\text { Carbon } \\
B\end{array}$ & $\begin{array}{l}\text { Type C-6-PVP } \\
\text { Celion } 12000 \\
\text { (12000 Filaments) }\end{array}$ & $\begin{array}{l}0.28 \times 10^{-3} \\
\left(7 \times 10^{-3}\right)\end{array}$ & $\begin{array}{c}0.25 \\
(6)\end{array}$ & Celanese \\
\hline Steel & $\begin{array}{l}\text { Smooth brass } \\
\text { coated wire, } \\
\text { Type } \mathrm{Hc} \mathrm{Br}\end{array}$ & $\begin{array}{l}0.016 \\
(0.41)\end{array}$ & $\begin{array}{l}0.75 \quad 1 \\
(19)\end{array}$ & National Standard C \\
\hline Glass & $\begin{array}{l}\text { Chopped Strand } \\
\text { Type } 3029 \\
\text { (203 Filaments) }\end{array}$ & & $\begin{array}{c}0.50 \\
(12.5)\end{array}$ & Owens Corning Glass \\
\hline Asbestos & While (Chrysotile) & $0.02-3010^{-3} \mathrm{~mm}$ & $\ldots$ & $\cdots$ \\
\hline
\end{tabular}
various parameters on the load deflection response is described next

\section{Effect of pressure}

The effect of pressure on the load deflection response was generally beneficial prior to first cracking lexcept in one case) and detrimental thereafter as shown in Figures

Table 3 Description of fibres

*Denier: Mass in grams of $9000 \mathrm{~m}$ of yarn.

Table 4 Properties of fibres used

\begin{tabular}{lcccc}
\hline $\begin{array}{l}\text { Properties } \\
\text { of } \\
\text { fibres }\end{array}$ & $\begin{array}{c}\text { Specific } \\
\text { gravity }\end{array}$ & $\begin{array}{c}\text { Tensile } \\
\text { strength } \\
\text { Ksi } \\
(\mathrm{MPa})\end{array}$ & $\begin{array}{c}\text { Elastic } \\
\text { modulus } \\
10^{3} \mathrm{Ksi} \\
\left(10^{3} \mathrm{MPa}\right)\end{array}$ & $\begin{array}{c}\text { Ultimate } \\
\text { elongation } \\
\text { percent }\end{array}$ \\
\hline Polypropylene & 0.91 & $80-111$ & 0.98 & 21 \\
Carbon & 1.77 & $(552-759)$ & $(6.7)$ & 1.5 \\
Steel Wire & $740-515$ & 34 & 7 \\
Glass & 7.86 & $100-120$ & $(235)$ & $2-3.5$ \\
Asbestos & 2.70 & $690-833$ & $(207)$ & $2-3$ \\
& 2.55 & $150-180$ & 10 & $(69)$ \\
\hline
\end{tabular}


(a)

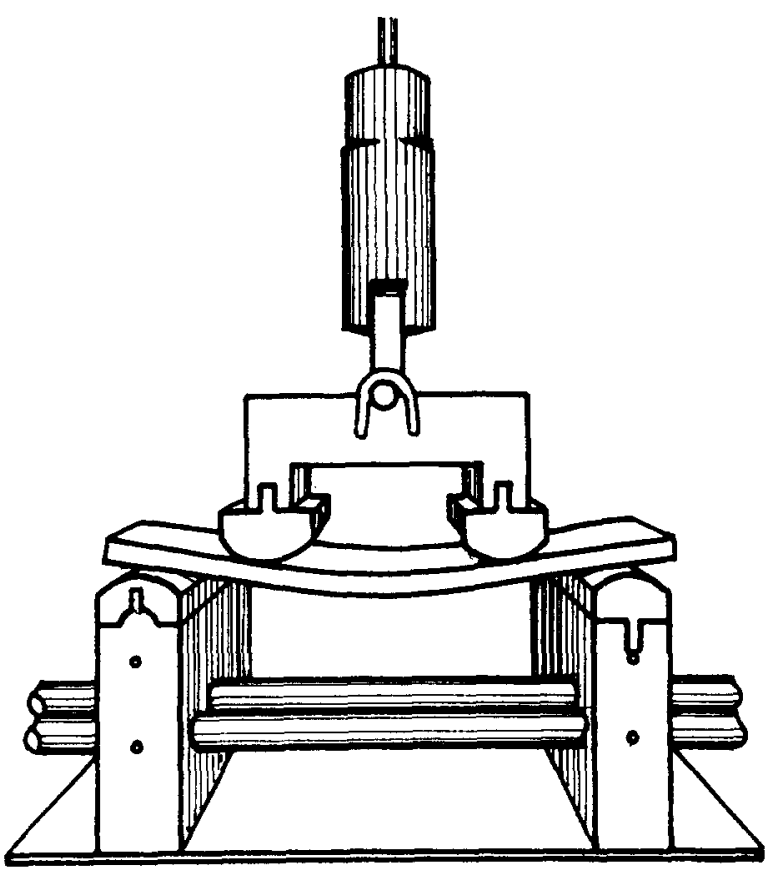

(b)

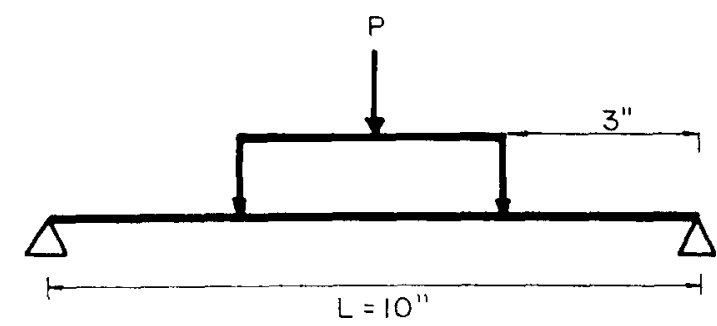

Figure 2 Test set-up. (a) Flexural specimen underload (b) Loading arrangement of flexural beams

3 and 4 . It can be seen from these figures that both the stress at first cracking and the slope of the stress deflection curve (or equivalently the elastic modulus) are, on the average, larger for the pressed series than for the unpressed ones. However, the properties of the pressed specimens deteriorate more rapidly after cracking leading to a smaller modulus of rupture (except for steel fibres) and a substantially smaller toughness due to premature failure. These effects are particularly noticeable in the case of polypropylene fibres but less significant for steel, glass, and carbon fibres (Figures 3 and 4).

References about fibre reinforced concrete performance when subjected to pressure after casting are scarce. Waller [5] subjected carbon fibre reinforced cement samples to pressure after casting to expel surplus water and entrapped air. He reported no improvement in strength. He attributed this result to the channelling produced by water flow which was large in relation to sample thickness.

In this study pressed specimens showed lower post-cracking stress and toughness than unpressed ones suggesting that pressure may have led to some

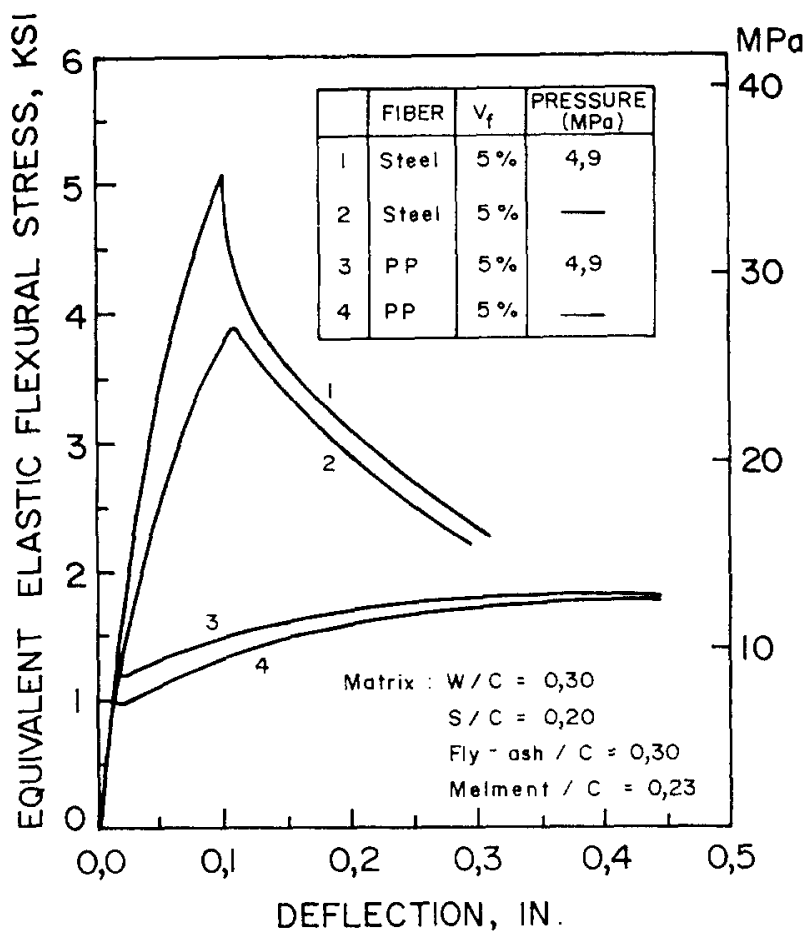

Figure 3 Typical effect of pressure casting on the loaddeflection curve of steel and PP fibre reinforced mortar

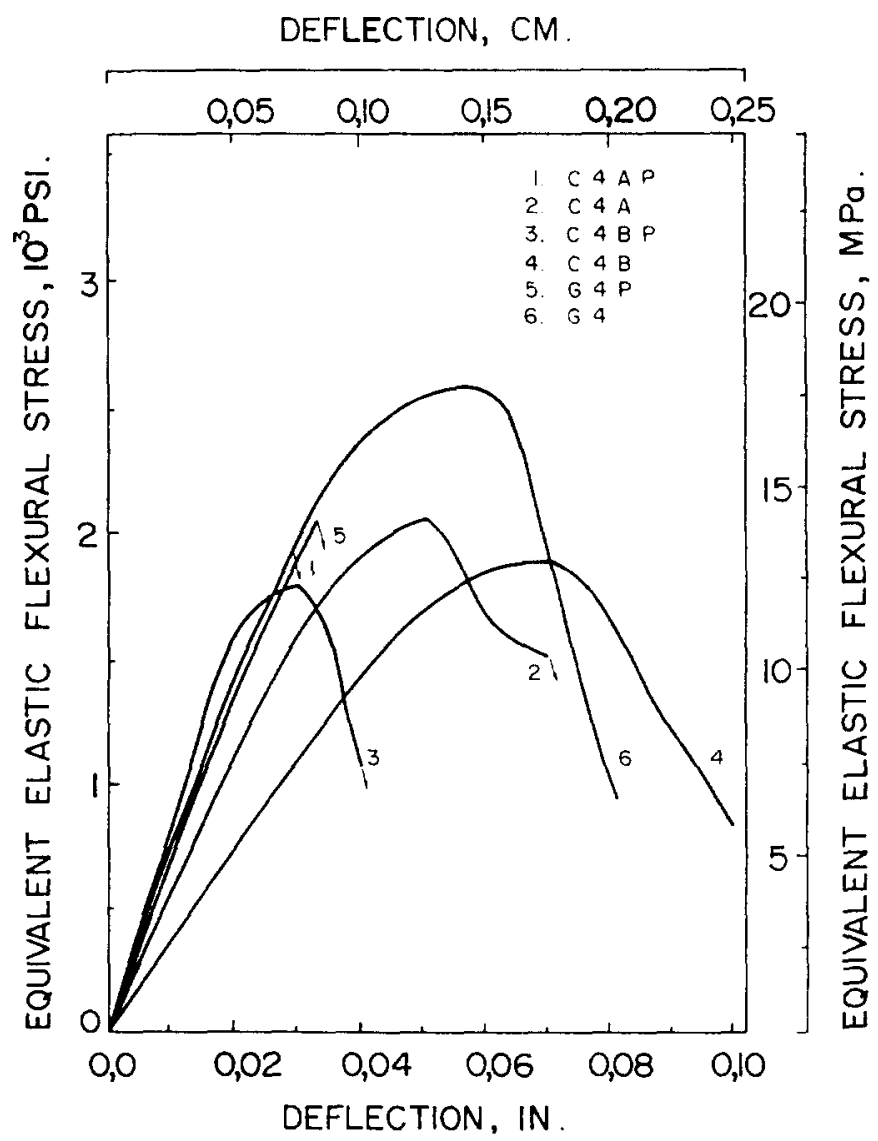

Figure 4 Typical effect of pressure casting on the loaddeflection curve of glass and carbon fibre reinforced mortar 
deterioration in either the bond at the fibre-matrix interface or the fibre itself. High fibre concentrations and excess water loss due to pressure may be other reasons for such deterioration.

Concentration of fibres due to pressure beyond a certain limit may be a relevant cause for a reduction in strength and toughness. Naaman and Shah [6] found that the pullout resistance (hence composite toughness) per fibre decreases when the number of fibres pulling out from the same area increases. $X$-ray analysis by Walkus et al. [7] indicates that failure cracks pass through scattered fibre zones. Patton and Whittaker [8] established that a group of fibres spaced closely enough interact to form a small area of high stiffness hence stress concentration. When this stress exceeds the strength of the inclusion, the region nucleates a failure crack, supporting the conclusion that tensile strength diminishes at very high fibre content.

Bleeding was induced during application of pressure. Ritchie and Rahman [9] analysed the extent of bleeding water in polypropylene and steel fibre rein forced concrete. They observed that bleeding water was held around individual fibres, hence a reduction in their bond strength. The amount of bleeding water decreased with an increase in fibre content and depended on the type and size of fibre. As bleeding is related to surface tension, the smoother the fibre (such as steel) the less bleeding water is retained and the more bleeding is observed.

A reduction in porosity of the cement paste thence an increase in strength) can be achieved, as done in this study, by a reduction in the water-cement ratio and by

Table 5 Summary of flexural test results

\begin{tabular}{|c|c|c|c|c|c|c|}
\hline \multirow{3}{*}{$\begin{array}{l}\text { Series } \\
\text { code }\end{array}$} & \multicolumn{2}{|c|}{$\begin{array}{l}\text { Limit of proportionality } \\
\text { (first crack) }\end{array}$} & \multicolumn{4}{|c|}{$\begin{array}{l}\text { Modulus of rupture (MOri } \\
\text { (Maximum load) }\end{array}$} \\
\hline & \multirow{2}{*}{$\begin{array}{l}\text { Average } \\
\text { strength } \\
\text { Psi (MPa) }\end{array}$} & \multirow{2}{*}{$\begin{array}{c}\text { Average } \\
\text { deflection } \\
\text { Inches }(\mathrm{mm})\end{array}$} & \multicolumn{2}{|c|}{$\begin{array}{l}\text { strength } \\
\text { Psi (MPd) }\end{array}$} & \multicolumn{2}{|c|}{$\begin{array}{l}\text { deflection } \\
\text { hohes mm? }\end{array}$} \\
\hline & & & Best & Average & Besi & Average \\
\hline P4AP1 & $1066(7.4)$ & $0.020(0.51)$ & $1899(13.0)$ & $1823(12.6)$ & $0.36(914)$ & $0.35(8.89)$ \\
\hline P4AP2 & $1150(7.9)$ & $0.030(0.76)$ & $1540(10.6)$ & $440(9.9)$ & $035(8.89)$ & $0.37(9.40)$ \\
\hline P4A & $860(5.9)$ & $0.020(0.51)$ & $3036(20.9)$ & $2490(17.2)$ & 1.051267 & $0.80(30.32)$ \\
\hline P5A5 P & $808(5.6)$ & $0.017(0.43)$ & $2100(14.5)$ & $2070(14.3)$ & $002(051)$ & $0.02(0.51)$ \\
\hline P5A5 & $1150(7.9)$ & $0.015(0.38)$ & $2772(19.1)$ & $2232(15.4)$ & $0.31(287)$ & $0.38(9.65)$ \\
\hline P5A3 P & $1198(8.3)$ & $0.013(0.33)$ & $1855(12.8)$ & $1855(12.8)$ & $0.06(-52\}$ & $0.06(1.52)$ \\
\hline P5A3 & $1050(7.2)$ & $0.018(0.46)$ & $1643(11.3)$ & $1500(10.3)$ & $0.37: 94$ & $0.38(9.65)$ \\
\hline PABP & $1263(8.7)$ & $0.017(0.43)$ & $1478(10.2)$ & $1333(92)$ & $0.14(356)$ & $0.12(3.05)$ \\
\hline P48 & $957(6.6)$ & $0.030(0.76)$ & $1183(8.2)$ & $158(80)$ & $0.37: 40$ & $0.41(1041)$ \\
\hline P5BP & $1065(7.3)$ & $0.020(0.51)$ & $1769(12.2)$ & $1556(10.7)$ & $0.21 \leq .33\}$ & $17(4.32)$ \\
\hline P5B & $907(6.3)$ & $0.018(0.46)$ & $2220(15.3)$ & $848(12.7)$ & $0.28,711$ & $0.26(6.60)$ \\
\hline P4CP & $1100(7.6)$ & $0.015(0.38)$ & $1497(10.3)$ & $491(10.3)$ & $0.08(2.03)$ & $0.14(3.56)$ \\
\hline P4C & $831(5.7)$ & $0.020(0.51)$ & $1460(10.1)$ & $410(9.7)$ & $0.54(1272)$ & $0.52(13.21)$ \\
\hline P5CP & $873(6.0)$ & $0.023(0.58)$ & $1246(8.6)$ & $1072(7.4)$ & $0.13+73:$ & $0.09(2.29)$ \\
\hline P5C & $959(6.6)$ & $0.022(0.56)$ & $1631(11.2)$ & $1529(10.5)$ & $0.45(1: 43)$ & $0.39(9.91)$ \\
\hline S4P & $1250(8.6)$ & $0.017(0.43)$ & $5139(35.4)$ & $5139(35.4)$ & $0.10(2.54)$ & $0.10(2.54)$ \\
\hline S4 & $1100(7.6)$ & $0.020(0.51)$ & $4274(29.5)$ & $3878(26.7)$ & $0.15(381)$ & $011: 279\}$ \\
\hline S5A1 & $1020(7.0)$ & $0.012(0.30)$ & $5094(35.1)$ & $4581(31.6)$ & $011(2.79)$ & $0.0(2.54)$ \\
\hline S5A5 & $1020(7.0)$ & $0.012(0.30)$ & $5798(40.0)$ & $5136(35.4)$ & $0.12(305)$ & $0.12(3.05)$ \\
\hline S5BP & $1245(8.6)$ & $0.020(0.51)$ & $1589(11.0)$ & $1538(10.6)$ & $0.03(0.76)$ & $0.03<0.76$ \\
\hline$S 5 B$ & $1117(7.7)$ & $0.013(0.33)$ & $2037(14.0)$ & $1897(13.2)$ & $0.06(-52)$ & $0.05(1.27)$ \\
\hline CAAP & $1066(7.4)$ & $0.017(0.43)$ & $1973(13.6)$ & $1920(13.2)$ & $0.03(0.76)$ & $0.03(0.76)$ \\
\hline $\mathrm{C} 4 \mathrm{~A}$ & $1070(7.4)$ & $0.020(0.51)$ & $2391(16.5)$ & $2052(14.2)$ & $0.07: 78$ & $0.05(1.27)$ \\
\hline C5AP & $1092(7.5)$ & $0.020(0.51)$ & $2063(14.2)$ & $1628(11.2)$ & $0.03(076)$ & $0.03: 0.76$ \\
\hline C5A & $1150(7.9)$ & $0.016(0.41)$ & $1814(12.5)$ & $1677(11.6)$ & $0.04: 1021$ & $0.03 / 0.76$ \\
\hline$C 4 B P$ & $1150(7.9)$ & $0.017(0.43)$ & $1792(12.4)$ & $1792(12.4)$ & $0.03(0.76)$ & $0.03: 0.76$ \\
\hline $\mathrm{C} 4 \mathrm{~B}$ & $1150(7.9)$ & $0.030(0.76)$ & $1882(13.0)$ & $1882(13.0)$ & $0.07(178)$ & $0.07 / 1.78$ \\
\hline $\mathrm{C} 5 \mathrm{BP}$ & $1278(8.8)$ & $0.018(0.46)$ & $1969(13.6)$ & $1758(12.1)$ & $0.03(0.76)$ & $0.03(0.76$ \\
\hline $\mathrm{C} 5 \mathrm{~B}$ & $1100(7.6)$ & $0.018(0.46)$ & $2538(17.5)$ & $2337(16.1)$ & $0.05(-27)$ & $0.05(1.27)$ \\
\hline $\mathrm{G} 4 \mathrm{P}$ & $1036(7.1)$ & $0.016(0.41)$ & $2035(14.0)$ & $2035(14.0)$ & $0.03(076)$ & $0.03(0.76)$ \\
\hline $\mathrm{G} 4$ & $996(6.9)$ & $0.012(0.30)$ & $2580(17.8)$ & $2472(17.0)$ & $0.06(-52)$ & $0.06(1.52)$ \\
\hline $\mathrm{G} 5 \mathrm{P}$ & $1260(8.7)$ & $0.020(0.51)$ & $1821(12.6)$ & $1624(11.2)$ & $002+0+1$ & $0.02 / 051$ \\
\hline 65 & $1000(6.9)$ & $0.018(0.46)$ & $1631(112)$ & $487(10.3)$ & $0.03: 0.76$ & $0.02+0.51$ \\
\hline $\mathrm{A} 5 \mathrm{P}$ & $1000(6.9)$ & $0.015(0.38)$ & $1220(8.4)$ & $1111: 7.7)$ & $003 ! 076$ & $0 . 0 2 \longdiv { 0 5 1 ! }$ \\
\hline$A 5$ & $980(6.8)$ & $0.017(0.43)$ & $1140(7.9)$ & $1062(73)$ & $0.02: 51$ & 0020511 \\
\hline
\end{tabular}


pressure compaction. However the addition of large amount of fibres tends to entrain or entrap air, increasing the porosity of the matrix. It seems that both air entrapment and bleeding will tend to balance the beneficial effects of reduced porosity and pressure casting. Hence a trade-off must be achieved in practice.

\section{Effect of matrix strength}

An increase in matrix strength is expected to lead to an increase in diversification at the fibre-matrix boundary. Everything else being equal it led to significant increases in the modulus of rupture and in the toughness of the composite. This is illustrated in Figures 5 and 6 for the series reinforced with polypropylene and steel fibres. The increase is primarily attributed to improvement in bond strength $[10,11]$, thus fibre efficiency. However as observed from Tables 5 and 6 it was often more than proportional to the increase in matrix tensile strength especially for the case of steel fibres. It is believed that, at high concentrations, steel fibres tend to interact between each other providing resistance even without the presence of the matrix.

\section{Effect of casting orientation and fibre content}

Everything else being equal specimens cast vertically along their width led to higher values in strength and

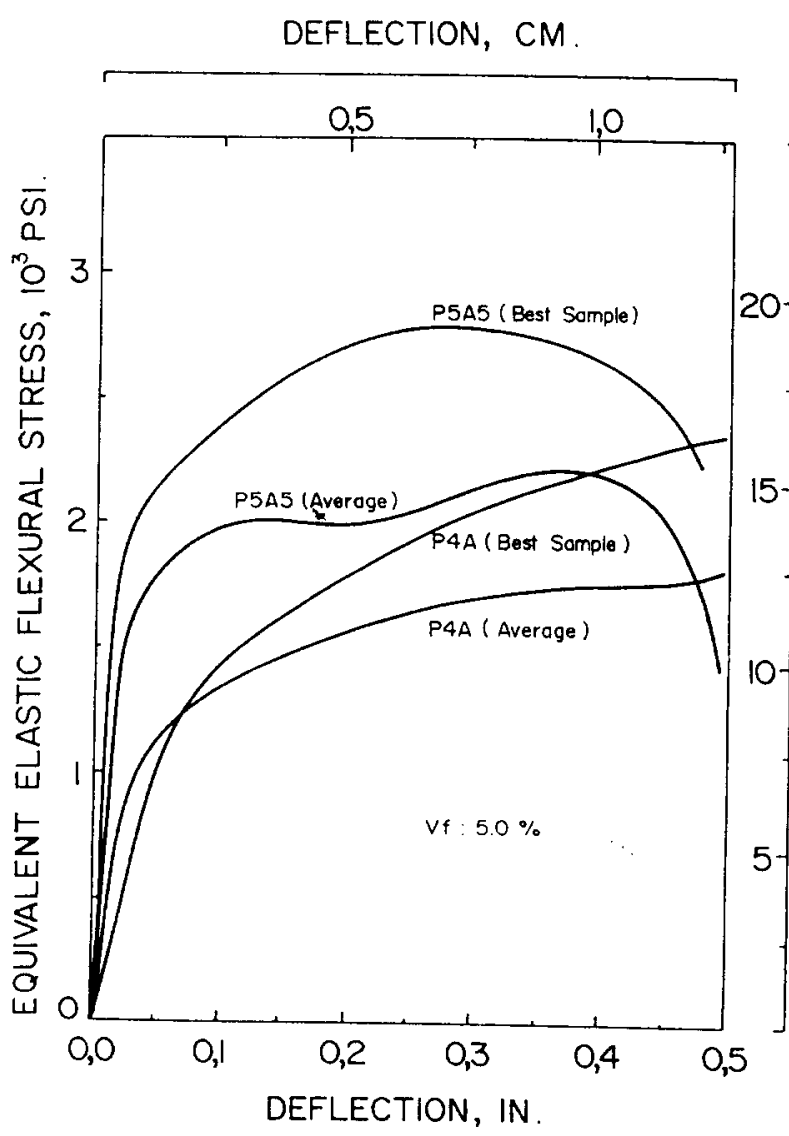

Figure 5 Effect of matrix compressive strength on the load-deflection response of PP fibre reinforced mortar toughness than specimens cast horizontally. A typical example is shown in Figure 7. This may be attributed to the better compaction achieved in vertically cast specimens, and, as reported by Moens and Nemegeer [12]. to induced fibre orientation during the filling process

As expected the higher the volume fraction of fibres the higher the modulus of rupture and the toughness of the composite. Typical results for polypropylene and steel fibre reinforced mortar beams are shown in Figures 8 and 9 . A volume fraction of fibres of $5 \%$ was about the maximum that could be mixed for the given matrix. For the same volume fraction of fibres, steel fibres led to a composite modulus of rupture about twice that achieved by polypropylene fibres. Moreover, because steel fibres are very stiff, the slope of the initial portion of the load

Table 6 Summary of average values of toughness index (Ref.3)

\begin{tabular}{|c|c|c|}
\hline \multirow[b]{2}{*}{$\begin{array}{l}\text { Series } \\
\text { code }\end{array}$} & \multicolumn{2}{|c|}{$\begin{array}{c}\text { Flexural toughness index } \\
\text { at deflection of: }\end{array}$} \\
\hline & $\begin{array}{l}0.075 \mathrm{in} \\
(1.9 \mathrm{~mm})\end{array}$ & $\begin{array}{c}0.5 \mathrm{in} \\
(12.5 \mathrm{~mm})\end{array}$ \\
\hline P4AP1 & 6.1 & 59.1 \\
\hline P4AP2 & 2.5 & 23.6 \\
\hline P4A & 6.2 & 88.8 \\
\hline P5A5P & 7.0 & 17.6 \\
\hline P5A5 & 8.6 & 80.9 \\
\hline P5A3P & 5.1 & 12.9 \\
\hline P5A3 & 7.0 & 72.5 \\
\hline P4BP & 6.0 & 25.2 \\
\hline $\mathrm{P} 4 \mathrm{~B}$ & 4.4 & 32.2 \\
\hline P5BP & 4.3 & 12.6 \\
\hline P5B & 5.3 & 41.0 \\
\hline P4CP & 11.4 & 41.6 \\
\hline$P 4 C$ & 8.0 & 54.6 \\
\hline P5CP & 6.3 & 18.7 \\
\hline P5C & 7.9 & 70.9 \\
\hline S4P & 3.5 & 27.9 \\
\hline S4 & 1.5 & 18.0 \\
\hline S5A1 & 4.5 & 30.3 \\
\hline S5A5 & 2.6 & 21.8 \\
\hline S5BP & 5.4 & 27.4 \\
\hline S5B & 8.3 & 47.6 \\
\hline C4AP & 1.9 & - \\
\hline C4A & 3.8 & - \\
\hline $\mathrm{C} 4 \mathrm{BP}$ & 4.6 & $\ldots$ \\
\hline $\mathrm{C} 4 \mathrm{~B}$ & 3.0 & - \\
\hline C5AP & 2.4 & - \\
\hline C5A & 6.4 & $\ldots$ \\
\hline C58P & 1.3 & - \\
\hline $\mathrm{C} 5 \mathrm{~B}$ & 1.3 & - \\
\hline G4P & 3.6 & - \\
\hline G4 & 6.5 & -- \\
\hline G5P & 3.3 & - \\
\hline G5 & 4.6 & - \\
\hline $\mathrm{A} 5 \mathrm{P}$ & 3.7 & - \\
\hline A5 & 3.6 & - \\
\hline
\end{tabular}




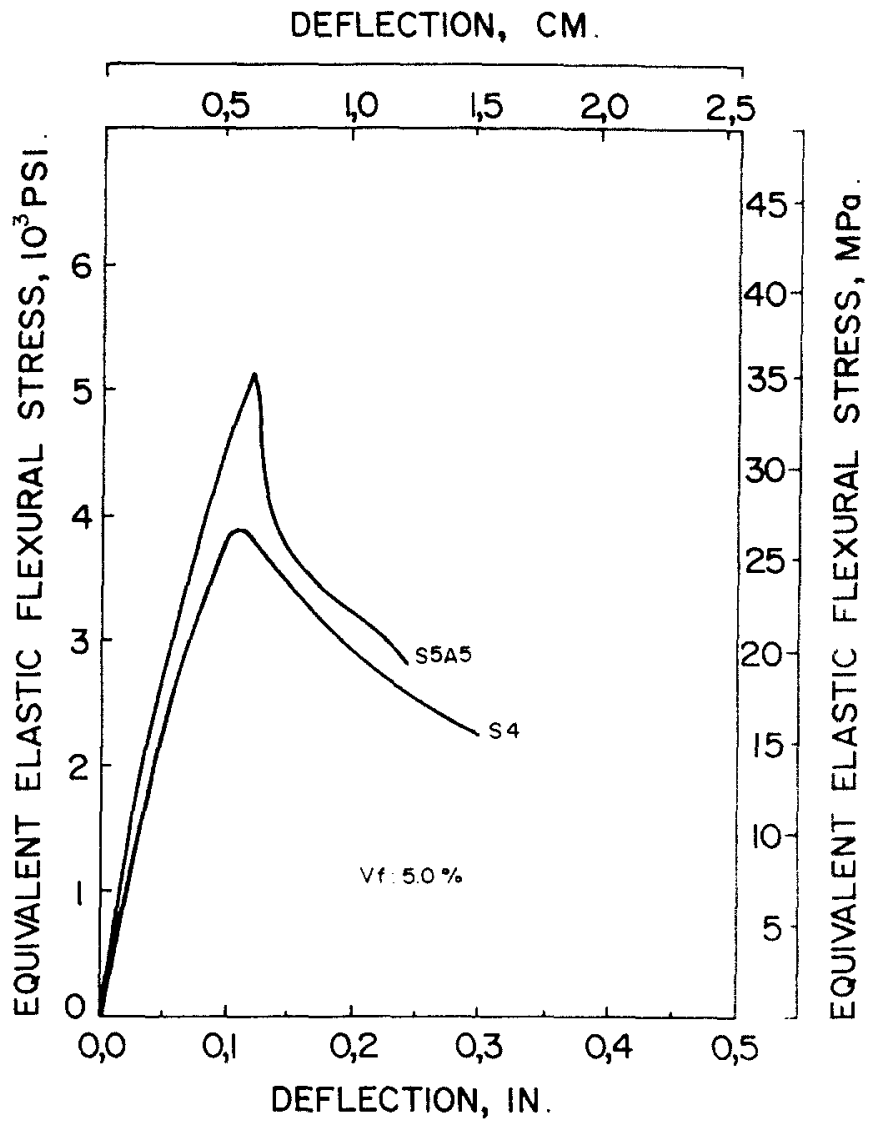

Figure 6 Effect of matrix compressive strength on the load-deflection response of steel fibre reinforced mortar

deflection curve remains quite linear up to very high stresses. This explains the high values of LOP reported in Table 4 which may not be real but just due to the inaccuracy of the method of measurement when a high volume of steel fibres is used

\section{Toughness}

One of the main benefits of adding fibres to a brittle matrix is to improve the energy absorption or toughness of the composite. Various methods to evaluate tough ness have been proposed in the technical literature [4. 14-201. So far, the most convenient one leads to a relative measure called toughness index and is recommended by $\mathrm{ACl}$ Committee 544 on fibre reinforced concrete [14] and the new ASTM Standard C1018-85 [20]. The toughness index is defined as the ratio of the area under the load deflection curve of the composite up to a specified deflection, to that up to the proportional limit or first crack strength. The latter value represents the energy absorbed by the unreinforced matrix. The deflection specified by $\mathrm{ACl}$ Committee 544 to determine the numerator is 0.075 in $(1.9 \mathrm{~mm})$ but it assumes different specimen dimensions and flexural stiffness. The toughness index for the test series of this study was determined assuming two values of limiting deflections,

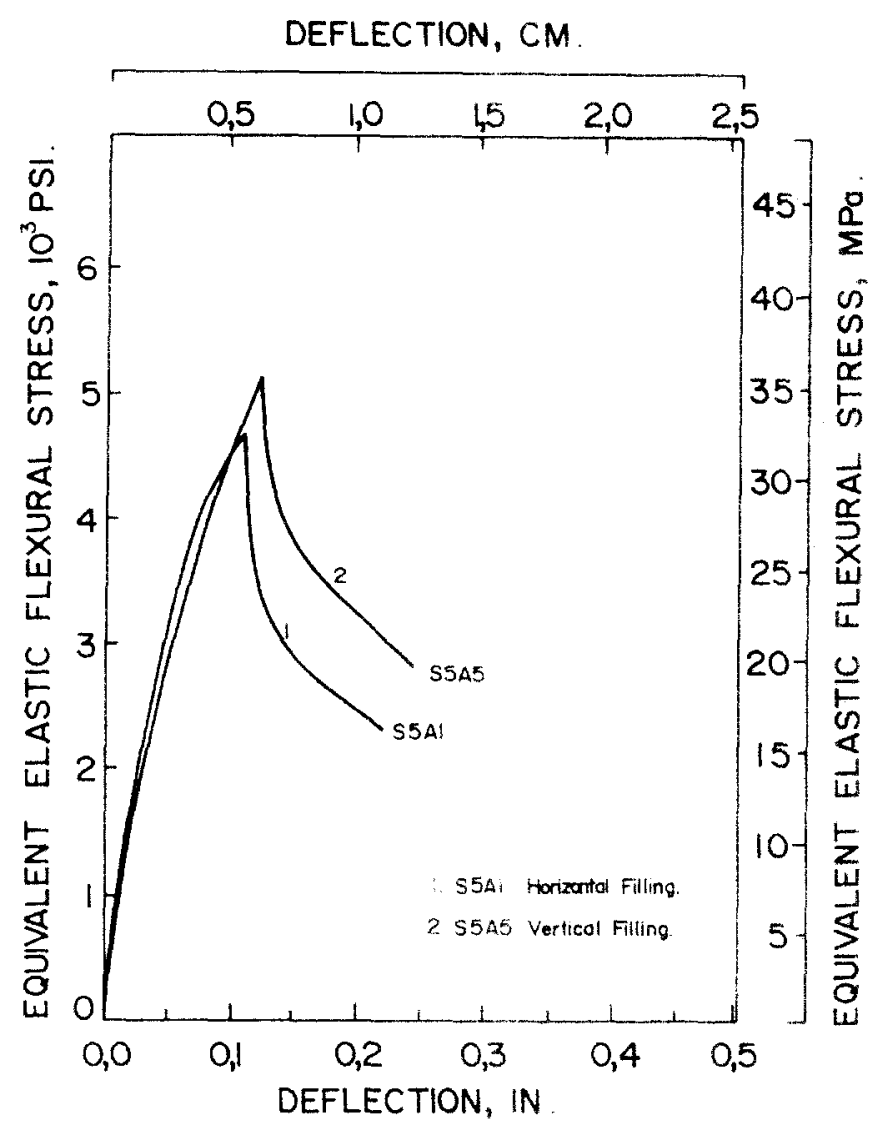

Figure 7 Effect of direction of casting on the loaddeflection response of steel fibre reinforced mortar

namely 0.075 in $11.9 \mathrm{~mm})$ and $0.5 \mathrm{in} 112.5 \mathrm{~mm}$. As observed from the stress-deflection curves (Figures 3 to 7). the latter value is more realistic for the specimens dimensions used here. Table 6 summarises the results obtained. Note that glass, carbon and asbestos fibre reinforced composites collapsed at a deflection less than $0.075 \mathrm{in}(1.9 \mathrm{~mm})$. Hence the same toughness index is recorded for 0.075 in $1.9 \mathrm{~mm}$ and 0.5 in $(12.5 \mathrm{~mm})$ deflections. It can also be seen that the addition of fibres to a mortar matrix leads to up to two orders of magnitude increase in its flexural toughness. The highest toughness index (88.8) was achieved with polypropylene fibres and was about twice the highest achieved by steel fibres (47.6). A much smaller toughness index ranging from 13 to 6.5 was obtained by the use of carbon, glass, or asbestos fibres.

It is noted that the new ASTM test [20] for flexural toughness was not followed here as it was not available at the time the experimental investigation took place.

\section{CONCLUSIONS}

On the basis of this study the following conclusions are drawn:

1. The application of short term (about 15 minutes) pressure of up to 1300 psi ( $9 \mathrm{MPa}$ ) to a freshly cast fibre 


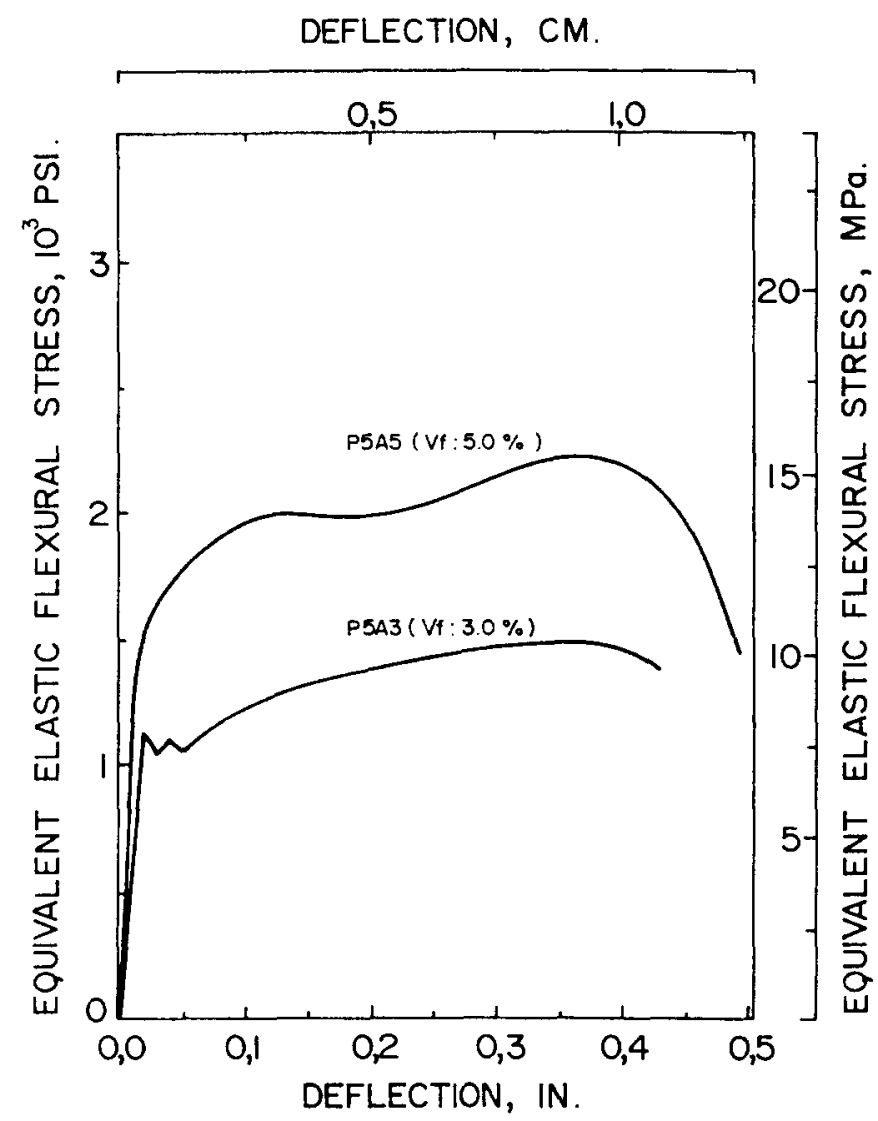

Figure 8 Effect of fibre content on the load-deflection response of PP fibre reinforced mortar

reinforced mortar leads to a slight increase in the proportional limit and elastic modulus of the resulting composite. However, it may also lead to a decrease in its modulus of rupture and its toughness

2. The benefits of applying pressure after casting to fibre reinforced mortar do not seem to justify the cost of implementing in practice such a process. Improvement in matrix and composite strength can be more effectively obtained by controlling the water-cement ratio of the mix, selecting the type and proportion of superplasticiser, and adding, the proper amount of mineral admixtures

3. Everything else being equal, an increase in the strength of the mortar matrix leads to an increase in the proportional limit, modulus of rupture and toughness of the resulting fibre reinforced composite.

4. Increase in both strength and toughness are observed when the direction of casting the tensile (wider) face of the flexural specimen is changed from horizontal to vertical.

5. Both the strength and toughness of fibre reinforced mortar increase with an increase in the volume fraction of fibres. However, in premixed fibre cement composites, an optimum limit may be obtained beyond which addition of fibres will not lead to any improvement.

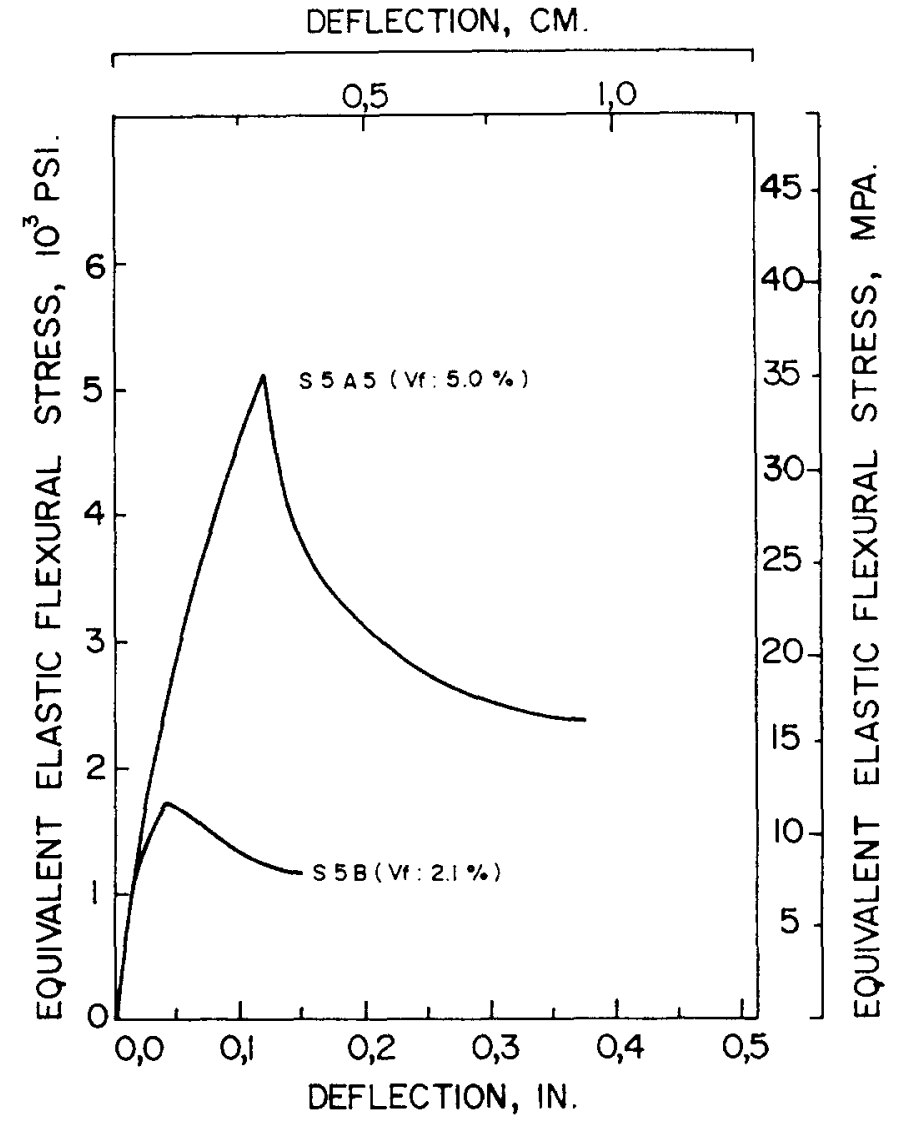

Figure 9 Effect of fibre content on the load-deflection response of steel fibre reinforced mortar

6. In comparing toughness values for different composites as derived from flexural tests, it is essential that the comparison be made at different deflections. Some fibres led to better composite performance at small deflections (steel, glass) while others (polypropylene) were superior for large deflections. This is also recommended in the new ASTM standard test for flexural toughness of fibre reinforced concrete [20].

\section{REFERENCES}

1. Naaman, A. E. High strength fibre reinforced cement composites. Proceedings, Symposium on The Potential of Very High Strength Cement-Based materials, J. F. Young, Editor, Vol. 42, Materials Research Society, Pittsburgh, 1985, pp. 217-29.

2. Naaman, A. E., and Homrich, J. R. Properties of high strength fibre reinforced concrete, in 'High strength concrete'. ACI Special Publication SP-87. H. G. Russell, Editor, Detroit, 1985, pp. 233-49.

3. Delvasto, Silvio, 'The flexural behaviour of pressed fibre reinforced hydraulic cementitious composites, approaching trials to obtain high resistance fibre reinforced composites', Thesis, University of Illinois at Chicago, 1984. 
4. Johnston, C. D. 'Definition and measurement of flexural toughness parameters for fibre reinforced concrete', Cement, Concrete and Aggregates, CCAGDP, Vol. 4, No. 2, Winter, 1982, pp. 53-60

5. Waller, J. A. 'Carbon fibre cement composites', International Symposium, American Concrete Institute, Publication SP-44, Detroit, 1974, pp. 143--61.

6. Naaman, A. E. and Shah, S. 'Pull-out mechanism in steel fibre reinforced concrete', Journal of the Structural Division. Proceedings of the American Society of Civil Engineers, Vol. 102, No. ST8, August 1976, pp. 1537-48.

7. Walkus, B. R., Januszkiewicz, A and Jeruzal, J. 'Concrete composites with cut steel fibre reinforcement subjected to uniaxial tension', $\mathrm{ACl}$ Journal, Proceedings, Vol. 70, No. 10, October 1979. pp. 1079-92

8. Patton, M. E. and Whittaker, W. L. 'Effects of fibre content and damaging load on steel fibre reinforced concrete stiffness', ACl Journal, Vol. 80. No. 1. January-February 1983, pp. 13-6

9. Ritchie, A. and Rahman, T. 'The effect of fibre reinforcements on the rheological properties of concrete mixes', International Symposium. American Concrete Institute, Publication SP -44, Detroit, 1974, pp.29-44.

10. Burakiewicz, A., 'Testing of fibre bond strength in cement matrix', RILEM Symposium on Testing and Test Methods of Fibre Cement Composites. The Construction Press, Lancaster, 1978, pp. 355--65

11. Swamy, R. N. and Mangat, P. 'The interfacial bond stress in steel fibre cement composites', Cement and Concrete Research, Vol. 6, No. 5, September 1976, pp. 641-9.

12. Moens, J. and Nemegeer, D. 'Flexural strength of fibre reinforced concrete test beams', Testing and
Test Methods of Fibre Cement Composites RILEM Symposium 1978. pp. 389-97

13. ACl Committee 544. 'State of the art report on fibre reinforced concrete', Report No. ACI 544. 1R-82 Concrete International, Vol. 4. No. 5, May 1982, pp 9-30.

14. American Concrete Institute (AC1), Committee 544 'Measurement of properties of fibre reinforced concrete', Journal ACl, Proceedings, Vol 75, No.7. July 1978. pp. 283-9.

15 Barr. B | G., Liu, K and Dowers, A. A toughness index to measure the energy absorption of fibre reinforced concrete', The International Journal of Cement Composites and Lightweight Concrete. vol. 4. No. 4, November 1982, pp. 22. ?

16. Visalvanich, K and Naaman, A. E. 'A fracture model for fibre reinforced concrete' Joumal of The American Concrete Institute. Vo 80, No. 2. March/April 1983. pp. 128-38

17. Schrader, E. 'Formulating guidance for testing of fibre concrete; Testing and Test Methods of Fibre Cement Composites. The Construction Press RILEM Symposium. Lancaster, 1978, pp. 9-21

18. Henager, C. H. 'A toughness index of fibre concrete'. Testing and Test Methods of Fibre Cement Composites, The Construction Press, RILEM Symposium, Lanacaster, 1978, pp. 79-36.

19. Nishioka, Kunio. 'Test method for the evaluation of the fracture of steel fibre reinforced concrete' Testing and Test Methods of Fibre Cement Compo sites. The Construction Press. RILEM Symposium: Lancaster, 1978 , pp. 87--93

20 Test Method for Flexural Toughness and Firs? Crack Strength of Fibre-Reinforced Concrete lusing Beam with Third Point Loading) ASTM, Standard C1018-85, Pittsburgh, 1985 